\title{
Preoperative systemic inflammation predicts postoperative infectious complications in patients undergoing curative resection for colorectal cancer
}

\author{
LH Moyes', EF Leitch', RF McKee', JH Anderson', PG Horgan' and DC McMillan*, \\ 'University Department of Surgery, Faculty of Medicine-University of Glasgow, Royal Infirmary, Glasgow G3I 2ER, UK
}

The presence of systemic inflammation before surgery, as evidenced by the glasgow prognostic score (mGPS), predicts poor longterm survival in colorectal cancer. The aim was to examine the relationship between the preoperative mGPS and the development of postoperative complications in patients undergoing potentially curative resection for colorectal cancer. Patients $(n=455)$ who underwent potentially curative resections between 2003 and 2007 were assessed consecutively, and details were recorded in a database. The majority of patients presented for elective surgery (85\%) were over the age of 65 years $(70 \%)$, were male (58\%), were deprived (53\%), and had TNM stage $1 / /$ disease (6l\%), had preoperative haemoglobin (56\%), white cell count (87\%) and mGPS 0 (58\%) in the normal range. After surgery, 86 (19\%) patients developed a postoperative complication; 70 (81\%) of which were infectious complications. On multivariate analysis, peritoneal soiling $(P<0.0 \mathrm{I})$, elevated preoperative white cell count $(P<0.05)$ and mGPS $(P<0.01)$ were independently associated with increased risk of developing a postoperative infection. In elective patients, only the $\mathrm{mGPS}(\mathrm{OR}=1.75,95 \% \mathrm{Cl}=1.17-2.63, P=0.007)$ was significantly associated with increased risk of developing a postoperative infection. Preoperative elevated mGPS predicts increased postoperative infectious complications in patients undergoing potentially curative resection for colorectal cancer.

British Journal of Cancer (2009) 1 00, 1236- 1239. doi: 10.1038/sj.bjc.6604997 www.bjcancer.com

Published online 24 March 2009

(C) 2009 Cancer Research UK

Keywords: colorectal cancer; surgery; glasgow prognostic score; infectious complications

Colorectal cancer remains the second most common cause of cancer death in Western Europe (Cancer Research UK, 2004). Despite advances in surgical techniques, perioperative care and adjuvant chemoradiotherapy, overall survival remains poor with only $50 \%$ patients surviving 5 years after potentially curative resection (McArdle and Hole, 2002).

Although tumour stage has been the main basis for predicting long-term survival in patients undergoing surgery for cancer, it is now recognised that postoperative complications contribute to poor cancer-specific survival (Rizk et al, 2004; Khuri et al, 2005; McArdle et al, 2005; Law et al, 2007). In particular, McArdle et al (2005) reported that in a prospective cohort of 2235 patients undergoing potentially curative resection for colorectal cancer, the postoperative complication of anastomotic leakage was associated with poorer cancer-specific survival, independent of Dukes stage. Law et al (2007) reported similar results in 1657 patients who underwent curative resection for colorectal cancer.

The basis of this observation is not clear. It has been postulated that the presence of an enhanced systemic inflammatory response may be responsible (McArdle et al, 2005), as the systemic inflammatory response, as evidenced by an elevated C-reactive

*Correspondence: Professor DC McMillan;

E-mail: d.c.mcmillan@clinmed.gla.ac.uk

Received 7 October 2008; revised 10 February 2009; accepted 26 February 2009; published online 24 March 2009 protein concentration, has been shown to be associated with poor cancer-specific survival, independent of tumour stage (Nielsen et al, 2000; McMillan et al, 2003; Crozier et al, 2006). Studies have shown that elevated C-reactive protein concentrations in the postoperative period may predict an increased chance of postoperative infection (Welsch et al, 2007) and anastomotic leakage (Matthiessen et al, 2008). An initial appraisal might suggest that early postoperative infection initially declares itself as a rise in C-reactive protein before overt clinical infection develops, and this infection causes decreased long-term survival. However, it has been reported that the preoperative, but not the immediate postoperative, elevated C-reactive protein concentrations are associated with cancer-specific survival (Crozier et al, 2007).

With respect to the measurement of the systemic inflammatory response the combination of C-reactive protein and albumin (glasgow prognostic score (mGPS)) has been shown to improve the prediction of cancer-specific survival in a variety of common solid tumours (McMillan, 2008) including primary operable colorectal cancer (McMillan et al, 2007; Ishizuka et al, 2007). To our knowledge, the relationship between the preoperative systemic inflammatory response and postoperative complications has not been examined previously.

The hypothesis underlying this study was that a preoperative systemic inflammatory response, as evidenced by the mGPS, may be an underlying host characteristic that predisposes to postoperative infection in patients undergoing potentially curative resection for colorectal cancer. 


\section{PATIENTS AND METHODS}

\section{Patients}

Patients with histologically proven colorectal cancer who, on the basis of laparotomy findings and/or preoperative abdominal computed tomography, were considered to have undergone a potentially curative resection and had routine laboratory measurement of white cell counts, albumin and C-reactive protein, between January 2003 and October 2007, at Glasgow Royal Infirmary, were prospectively included in the study. The antibiotic regimen was based on $1 \mathrm{~g}$ second-generation cephalosporin and $500 \mathrm{mg}$ metronidazole at induction of general anaesthesia. No other antibiotics were normally given. Three consultant surgeons (Anderson, Horgan and McKee) performed the majority of the operations (79\%). The surgical approach was open in all cases.

Patients were assessed consecutively and their details were recorded in our colorectal cancer database. The tumours were staged according to the TNM criteria (American Joint Committee on Cancer Colon and rectum, 2002). Patients who had preoperative clinical evidence of infection or other inflammatory conditions were excluded from the study. A total of 23 patients were excluded on the basis of these criteria.

The extent of deprivation was defined using the Carstairs deprivation index (Carstairs and Morris, 1991). This is an areabased measure derived from the 2001 census, using the postcode of residence at diagnosis, which divides the score into a sevenpoint index. For illustrative purposes, these results are presented by amalgamating the seven categories into three groups: affluent (categories 1 and 2), intermediate (categories 3-5) and deprived (categories 6 and 7). The Carstairs deprivation index has been extensively utilised in cancer patients, and is particularly appropriate for use in the central belt of Scotland (Hole and McArdle, 2002).

Patients were assessed for the following complications: infectious (wound infection, intra-abdominal abscess, anastomotic leak, pneumonia and septicaemia) and noninfectious (cardiac events encompassing acute coronary syndrome and acute myocardial infarction and pulmonary embolism). The criteria used to define infectious complications were the same as that described previously (Ytting et al, 2005). (1) Wound infection was defined as the presence of pus, either discharged spontaneously or requiring drainage. Wound infection included a subgroup of patients with perineal infection, following abdominoperineal resection of the rectum. (2) Intra-abdominal abscess was verified by either surgical drainage or by ultrasonographically guided aspiration of pus. (3) Anastomotic leakage was defined as radiologically verified fistula to bowel anastomosis or diagnosed by relaparatomy. (4) Pneumonia was defined by fever above $38.5^{\circ} \mathrm{C}$ and a positive X-ray, and requirement of antibiotic treatment. (5) Septicaemia was defined by clinical symptoms combined with a positive blood culture.

Non-symptomatic or minor urinary tract infection was not recorded, and therefore only included if complicated by septicaemia.

The study was approved by the Research Ethics Committee, Royal Infirmary, Glasgow.

\section{Blood parameters}

Routine preoperative laboratory measurements of white cell count, albumin and C-reactive protein concentration were carried out. The coefficient of variation for these methods, over the range of measurement, was $<10 \%$ as established by routine quality control procedures.

The mGPS was constructed as described previously (McMillan et al, 2007). Briefly, a normal albumin $\left(>35 \mathrm{gl}^{-1}\right)$ and normal C-reactive protein $\left(<10 \mathrm{mgl}^{-1}\right)$ scores 0 , with an elevated C-reactive protein scoring 1 and an elevated C-reactive protein together with a low albumin scoring 2 .

\section{Statistics}

Data are presented as median (range). Grouping of the variables was carried out using standard thresholds. Comparisons between groups of patients were carried out using the Mantel-Haenszel $\left(\chi^{2}\right)$ test for trend as appropriate. Logistic regression analysis was used to examine the effect of variables on the development of postoperative infection. Analysis was performed using SPSS software (SPSS for Windows Version 15.0, SPSS Inc., Chicago, IL, USA).

\section{RESULTS}

The relationship between the preoperative systemic inflammatory response (mGPS) and clinicopathological characteristics in

Table I The relationship between the preoperative systemic inflammatory response (mGPS) and clinicopathological characteristics in patients undergoing potentially curative surgery for colorectal cancer $(n=455)$

\begin{tabular}{|c|c|c|c|c|}
\hline & $\begin{array}{c}\text { mGPS } 0 \\
n=259(\%)\end{array}$ & $\begin{array}{c}\text { mGPS I } \\
n=130(\%)\end{array}$ & $\begin{array}{l}\text { mGPS } 2 \\
n=66(\%)\end{array}$ & $P$-value \\
\hline \multicolumn{5}{|l|}{ Age } \\
\hline $\begin{array}{l}<65 \text { years } \\
65-74 \text { years } \\
\geqslant 75 \text { years }\end{array}$ & $\begin{array}{l}88(34) \\
88(34) \\
83(32)\end{array}$ & $\begin{array}{l}28(28) \\
46(35) \\
48(37)\end{array}$ & $\begin{array}{l}22(33) \\
18(27) \\
26(40)\end{array}$ & 0.283 \\
\hline \multicolumn{5}{|l|}{ Sex } \\
\hline $\begin{array}{l}\text { Female } \\
\text { Male }\end{array}$ & $\begin{array}{r}98(38) \\
|6|(62)\end{array}$ & $\begin{array}{l}62(48) \\
68(52)\end{array}$ & $\begin{array}{l}30(46) \\
36(54)\end{array}$ & 0.102 \\
\hline \multicolumn{5}{|l|}{ Deprivation } \\
\hline $\begin{array}{l}\text { Affluent }(1,2) \\
\text { Intermediate }(3,4,5)\end{array}$ & $\begin{array}{l}15(6) \\
118(46)\end{array}$ & $\begin{aligned} 1 & (1) \\
53 & (40)\end{aligned}$ & $\begin{array}{c}2(3) \\
24(36)\end{array}$ & \\
\hline Deprived $(6,7)$ & $126(48)$ & $76(59)$ & $40(61)$ & 0.014 \\
\hline \multicolumn{5}{|l|}{ Presentation } \\
\hline Elective & $245(95)$ & $100(77)$ & $40(6 I)$ & \\
\hline Emergency & $14(5)$ & $30(23)$ & $26(39)$ & $<0.001$ \\
\hline \multicolumn{5}{|l|}{ Peritoneal soiling } \\
\hline None or serous fluid & $256(98 \%)$ & $126(97 \%)$ & $61(92 \%)$ & \\
\hline Local pus & $2(1 \%)$ & $4(3 \%)$ & $4(6 \%)$ & \\
\hline Free pus or faeces & I (1\%) & $0(0 \%)$ & I (2\%) & 0.010 \\
\hline \multicolumn{5}{|l|}{ Tumour site } \\
\hline Colon & $128(49)$ & $93(72)$ & $54(82)$ & \\
\hline Rectum & $|3|(5 \mid)$ & $37(28)$ & $12(18)$ & $<0.001$ \\
\hline \multicolumn{5}{|l|}{ Tumour } \\
\hline $\mathrm{TI}$ & $24(9)$ & $3(2)$ & $0(0)$ & \\
\hline $\mathrm{T} 2$ & $48(19)$ & $9(7)$ & $4(6)$ & \\
\hline T3 & $128(49)$ & $69(53)$ & $33(50)$ & \\
\hline $\mathrm{T} 4$ & $59(23)$ & $49(38)$ & $29(44)$ & $<0.001$ \\
\hline \multicolumn{5}{|l|}{ Nodal involvement } \\
\hline No & $164(63)$ & $75(58)$ & $37(56)$ & \\
\hline $\mathrm{NI}$ & $72(28)$ & $34(26)$ & $22(33)$ & \\
\hline N2 & $23(9)$ & $21(16)$ & $7(11)$ & 0.148 \\
\hline \multicolumn{5}{|l|}{ TNM stage } \\
\hline 1 & $63(24)$ & $10(8)$ & $4(6)$ & \\
\hline$\|$ & 102 (39) & $68(52)$ & $33(50)$ & \\
\hline III & 94 (37) & $52(40)$ & $29(44)$ & 0.001 \\
\hline \multicolumn{5}{|l|}{ Haemoglobin } \\
\hline$\geqslant 12 \mathrm{~g}$ per $100 \mathrm{ml}$ & $180(70)$ & $64(49)$ & $11(17)$ & \\
\hline$<12 \mathrm{~g}$ per $100 \mathrm{ml}$ & $79(30)$ & $66(51)$ & $55(83)$ & $<0.001$ \\
\hline \multicolumn{5}{|l|}{ White cell count } \\
\hline$<8.5 \times 10^{9} / \|$ & 191 (74) & $63(49)$ & $26(39)$ & \\
\hline $8.5-11.0 \times 10^{9} / 1$ & $52(20)$ & $42(32)$ & $24(37)$ & \\
\hline$>11 \times 10^{9} / 1$ & $16(6)$ & $25(19)$ & $16(24)$ & $<0.001$ \\
\hline \multicolumn{5}{|l|}{ Complications } \\
\hline None & $223(86)$ & $105(8 \mid)$ & $41(62)$ & \\
\hline Infectious & $25(10)$ & $21(16)$ & $24(36)$ & \\
\hline Non-infectious & II (4) & $4(3)$ & I (2) & 0.004 \\
\hline
\end{tabular}


Table 2 The relationship between the studied variables and postoperative infection in patients undergoing potentially curative surgery for colorectal cancer $(n=455)$.

\begin{tabular}{|c|c|c|c|c|}
\hline & $\begin{array}{l}\text { Univariate odds } \\
\text { ratio }(95 \% \mathrm{Cl})\end{array}$ & $P$-value & $\begin{array}{l}\text { Multivariate odds } \\
\text { ratio }(95 \% \mathrm{Cl})\end{array}$ & $P$-value \\
\hline Age $(<65 / 65-74 / \geqslant 75$ years $)$ & $1.01(0.74-1.38)$ & 0.961 & & \\
\hline Deprivation $(1-2 / 3-5 / 6-7)$ & $1.51(0.94-2.42)$ & 0.089 & & 0.335 \\
\hline Presentation (elective/emergency) & $3.52(1.96-6.32)$ & $<0.001$ & & 0.058 \\
\hline Peritoneal soiling (none or serous fluid/local pus/free pus or faeces) & $7.17(2.35-21.86)$ & 0.001 & $4.91(1.60-15.08)$ & 0.005 \\
\hline Tumour site (colon/rectum) & $1.02(0.61-1.72)$ & 0.935 & & \\
\hline TNM stage $(|/ /| / / I \mid)$ & $0.97(0.68-1.38)$ & 0.844 & & \\
\hline Haemoglobin $(\geqslant 12 /<12$ g per $100 \mathrm{mll})$ & $1.53(0.92-2.55)$ & 0.104 & & \\
\hline White cell count $\left(<8.0 / 8.5-11.0 />1\left|\times 10^{9} /\right|\right)$ & $1.95(1.41-2.72)$ & $<0.001$ & $1.46(1.01-2.11)$ & 0.043 \\
\hline C-reactive protein $\left(\leqslant|0 />| 0 \mathrm{mg}^{-1}\right)$ & $2.79(1.64-4.74)$ & $<0.001$ & & \\
\hline Albumin $\left(\geqslant 35 /<35 \mathrm{gl}^{-1}\right)$ & $3.14(1.80-5.48)$ & $<0.001$ & & \\
\hline mGPS $(0 / 1 / 2)$ & $2.28(1.64-3.16)$ & $<0.001$ & $1.76(1.22-2.55)$ & 0.003 \\
\hline
\end{tabular}

patients $(n=455)$ who underwent curative surgery for colorectal cancer is shown in Table 1 . The majority of patients were over the age of 65 years $(70 \%)$, were male $(58 \%)$, were deprived $(53 \%)$, and presented for elective surgery $(85 \%)$. The majority of patients presented with colonic tumours $(60 \%)$ had T3-4 disease $(81 \%)$, no nodal involvement (61\%) and had TNM stage I/II disease (61\%). The majority of patients had preoperative haemoglobin (56\%), white cell count $(87 \%)$ and mGPS $0(58 \%)$ in the normal range.

After surgery, $86(19 \%)$ patients developed a postoperative complication; $70(81 \%)$ of which were infectious complications. The 16 non-infectious events were pulmonary embolism $(n=1)$, myocardial infarction $(n=6)$, acute coronary syndrome $(n=5)$ and acute onset atrial fibrillation $(n=4)$. The 70 infectious events were septicaemia $(n=6)$, pneumonia $(n=33)$, anastomotic leak $(n=14)$, intra-abdominal collection $(n=2)$ and wound infection $(n=15)$.

An elevated mGPS was associated with deprivation $(P<0.05)$, emergency presentation $(P<0.001)$, peritoneal soiling $(P \leqslant 0.01)$ colonic tumours $(P<0.001)$, advanced tumour stage $(P<0.01)$, low haemoglobin $(P<0.001)$, high white cell count $(P<0.001)$ and postoperative infections $(P<0.01)$.

The relationship between clinicopathological characteristics, systemic inflammatory response and postoperative infections in patients undergoing surgery for colorectal cancer is shown in Table 2. On binary logistic regression analysis, deprivation $(P<0.10)$, emergency presentation $(P<0.001)$, peritoneal soiling $(P=0.001)$, elevated preoperative white cell count $(P<0.001)$, C-reactive protein $(P<0.001)$, albumin $(P<0.001)$ and mGPS $(<0.001)$ were associated with increased risk of developing a postoperative infection. On multivariate analysis, peritoneal soiling $(P<0.01)$, elevated preoperative white cell count $(P<0.05)$ and mGPS $(P<0.01)$ were independently associated with increased risk of developing a postoperative infection.

When only those patients who presented electively were considered in the analysis $(n=385)$, on binary logistic regression analysis, only the mGPS $(\mathrm{OR}=1.75,95 \% \mathrm{CI}=1.17-2.63$, $P=0.007)$ was significantly associated with increased risk of developing a postoperative infection.

\section{DISCUSSION}

The results of this study show that the preoperative systemic inflammatory response, as evidenced by the mGPS, was independently associated with an increased risk of postoperative infectious complications in patients undergoing potentially curative resection for colorectal cancer. This relationship persisted after patients with an emergency presentation were excluded from the logistic regression analysis. Given that postoperative infections are relatively common in patients undergoing surgery for colorectal cancer and are associated with increased hospital stay and treatment costs, it may be that the simple routinely available preoperative measurement of the mGPS will be clinically useful in identifying patients at high risk of developing infectious complications.

The basis of the independent relationship between an elevated mGPS before surgery and postoperative infections in patients with primary operable colorectal cancer is not clear. A plausible explanation is that an elevated mGPS may reflect compromised cell-mediated immunity as C-reactive protein is associated with lymphopenia (Nozoe et al, 2000; Leitch et al, 2007) and an impaired T-lymphocytic response (Canna et al, 2005) in patients with colorectal tumours. Alternatively, C-reactive protein is also associated with components of the innate immune system, including complement, and this response may also be compromised (Du Clos and Mold, 2004; Ytting et al, 2006). Also, an mGPS of 2, based as it is on the presence of an ongoing systemic inflammatory response and hypoalbuminaemia, reflects the loss of lean tissue and protein (McMillan et al, 1998; McMillan et al, 2001), which is likely to further compromise immune function. Therefore, the results of this study suggest that compromised immune function may occur before surgery and influences postoperative infectious complications.

It was of interest that, in this study, an elevated preoperative white cell count was also independently associated with increased risk of postoperative infectious complications. However, the white cell count was strongly associated with mGPS, and compared with the mGPS, the significance of its association weakened on multivariate analysis. Furthermore, in those patients who presented electively, white cell count was no longer significantly associated with postoperative infection. This would support the routine use of the mGPS to identify patients at increased risk of developing infectious complications. However, it remains to be determined whether the preoperative systemic inflammatory response may be moderated and whether such moderation may reduce postoperative infectious complications.

In summary, the results of this study indicate that a simple inflammation-based prognostic score identifies patients at increased risk of developing infectious complications following potentially curative resection for colorectal cancer.

\section{ACKNOWLEDGEMENTS}

We gratefully acknowledge the interest and encouragement of Mr Ian G Finlay and Professor Colin S McArdle, Royal Infirmary, Glasgow. 


\section{REFERENCES}

American Joint Committee on Cancer Colon and rectum (2002) In AJCC Cancer Staging Manual Greene FL, Page DL, Fleming ID, Fritz A, Balch CM, Haller DG, Morrow M (eds) 6th edn, pp 113-124. Springer: New York, NY

Cancer Research UK (2004) In CancerStats Monograph 2004: Cancer Incidence, Survival and Mortality in the UK and EU, Toms JR (ed). Cancer Research UK: London, UK

Canna K, McArdle PA, McMillan DC, McNicol AM, Smith GW, McKee RF, McArdle CS (2005) The relationship between tumour T-lymphocyte infiltration, the systemic inflammatory response and survival in patients undergoing curative resection for colorectal cancer. $\mathrm{Br}$ J Cancer 92: $651-654$

Carstairs V, Morris R (1991) Deprivation and Health in Scotland. University Press: Aberdeen

Crozier JE, McKee RF, McArdle CS, Angerson WJ, Anderson JH, Horgan PG, McMillan DC (2006) The presence of a systemic inflammatory response predicts poorer survival in patients receiving adjuvant 5-FU chemotherapy following potentially curative resection for colorectal cancer. Br J Cancer 94: 1833-1836

Crozier JE, McKee RF, McArdle CS, Angerson WJ, Anderson JH, Horgan PG, McMillan DC (2007) Preoperative but not postoperative systemic inflammatory response correlates with survival in colorectal cancer. Br J Surg 94: $1028-1032$

Du Clos TW, Mold C (2004) C-reactive protein: an activator of innate immunity and a modulator of adaptive immunity. Immunol Res 30: $261-277$

Hole DJ, McArdle CS (2002) Impact of socioeconomic deprivation on outcome after surgery for colorectal cancer. Br J Surg 89: 586-590

Ishizuka M, Nagata H, Takagi K, Horie T, Kubota K (2007) Inflammationbased prognostic score is a novel predictor of postoperative outcome in patients with colorectal cancer. Ann Surg 246: 1047-1051

Participants in the VA National Surgical Quality Improvement ProgramKhuri SF, Henderson WG, DePalma RG, Mosca C, Healey NA, Kumbhani DJ (2005) Determinants of long-term survival after major surgery and the adverse effect of postoperative complications. Ann Surg 242: $326-341$

Law WL, Choi HK, Lee YM, Ho JW (2007) The impact of postoperative complications on long-term outcomes following curative resection for colorectal cancer. Ann Surg Oncol 14: 2559-2566

Leitch EF, Chakrabarti M, Crozier JE, McKee RF, Anderson JH, Horgan PG, McMillan DC (2007) Comparison of the prognostic value of selected markers of the systemic inflammatory response in patients with colorectal cancer. Br J Cancer 97: 1266-1270

Matthiessen P, Henriksson M, Hallböök O, Grunditz E, Norén B, Arbman G (2008) Increase of serum C-reactive protein is an early indicator of subsequent symptomatic anastomotic leakage after anterior resection. Colorectal Dis 10: $75-80$

McArdle CS, Hole DJ (2002) Outcome following surgery for colorectal cancer: analysis by hospital after adjustment for case-mix and deprivation. $\mathrm{Br}$ J Cancer 86: 331 - 335

McArdle CS, McMillan DC, Hole DJ (2005) Impact of anastomotic leakage on long-term survival of patients undergoing curative resection for colorectal cancer. Br J Surg 92: $1150-1154$

McMillan DC (2008) An inflammation-based prognostic score and its role in the nutrition-based management of patients with cancer. Proc Nutr Soc 67: $257-262$

McMillan DC, Canna K, McArdle CS (2003) Systemic inflammatory response predicts survival following curative resection of colorectal cancer. Br J Surg 90: 215-219

McMillan DC, Crozier JE, Canna K, Angerson WJ, McArdle CS (2007) Evaluation of an inflammation-based prognostic score (GPS) in patients undergoing resection for colon and rectal cancer. Int J Colorectal Dis 22: 881-886

McMillan DC, Scott HR, Watson WS, Preston T, Milroy R, McArdle CS (1998) Longitudinal study of body cell mass depletion and the inflammatory response in cancer patients. Nutr Cancer 31: $101-105$

McMillan DC, Watson WS, O'Gorman P, Preston T, Scott HR, McArdle CS (2001) Albumin concentrations are primarily determined by the body cell mass and the systemic inflammatory response in cancer patients with weight loss. Nutr Cancer 39: 210-213

Nielsen HJ, Christensen IJ, Sørensen S, Moesgaard F, Brünner N (2000) Preoperative plasma plasminogen activator inhibitor type-1 and serum C-reactive protein levels in patients with colorectal cancer. The RANX05 Colorectal Cancer Study Group. Ann Surg Oncol 7: 617-623

Nozoe T, Matsumata T, Sugimachi K (2000) Preoperative elevation of serum C-reactive protein is related to impaired immunity in patients with colorectal cancer. Am J Clin Oncol 23: 263-266

Rizk NP, Bach PB, Schrag D, Bains MS, Turnbull AD, Karpeh M, Brennan MF, Rusch VW (2004) The impact of complications on outcomes after resection for esophageal and gastroesophageal junction carcinoma. J Am Coll Surg 198: $42-50$

Welsch T, Müller SA, Ulrich A, Kischlat A, Hinz U, Kienle P, Büchler MW, Schmidt J, Schmied BM (2007) C-reactive protein as early predictor for infectious postoperative complications in rectal surgery. Int J Colorectal Dis 22: $1499-1507$

Ytting H, Christensen IJ, Basse L, Lykke J, Thiel S, Jensenius JC, Nielsen HJ (2006) Influence of major surgery on the mannan-binding lectin pathway of innate immunity. Clin Exp Immunol 144: 239-246

Ytting H, Christensen IJ, Jensenius JC, Thiel S, Nielsen HJ (2005) Preoperative mannan-binding lectin pathway and prognosis in colorectal cancer. Cancer Immunol Immunother 54: 265-272 